\title{
Globalization, Transnational Corporations and Human Rights - A New Paradigm
}

\author{
Jennifer Westaway ${ }^{1}$ \\ ${ }^{1}$ School of Business Law and Taxation, Curtin University, Perth, Australia \\ Correspondence: Jennifer Westaway, School of Business Law and Taxation, Curtin University, GPO Box U1987, \\ Perth, 6957, Western Australia. Tel: 61-892-666-3945. E-mail: jennifer.westaway@cbs.curtin.edu.au
}

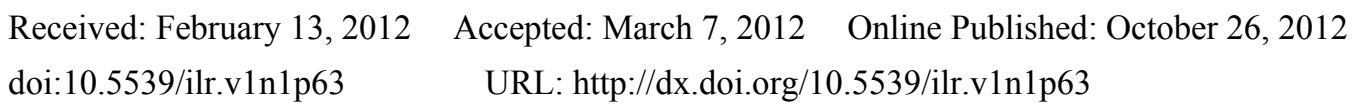

\begin{abstract}
The growth in power and influence of the transnational corporation under the forces of globalization has been touted as being one of the most significant developments both domestically and internationally. Changes to economic, political and financial barriers by many developing countries with the hope to attract international investment have seen the move by transnational corporations to exploit these opportunities. There are many who argue that the impact of transnational corporations has been positive, providing employment and income opportunities as well as country wealth. There are however, many who argue that the power and influence of the transnational corporation brings with it the ability to directly impact adversely on human rights and that as the transnational corporation operates outside human rights obligations assumed by each state pursuant to their status under international conventions, there needs to be a new human rights dialogue. This paper addresses the significance of the transnational corporation, the role of the transnational corporation in the context of human rights and concludes that as a result of the global financial crisis that we have lost the focus on traditional concerns for human rights violations and allowed economic and financial sustainability concerns to become paramount.
\end{abstract}

Keywords: globalization, human rights, transnational corporation, sovereignty, global financial crisis

\section{Introduction}

The relationship between the processes of globalization and human rights has been the focus of much debate, both within academia and the global human rights community. Much of this debate has focused on the power and influence of transnational corporations. It is clear that the rise in the power and influence of transnational corporations both domestically and internationally, can be attributed to the processes of economic globalization. National economies have over recent years been reducing the political and financial barriers which have limited their ability to engage in trade activities and attract foreign investment. Multinational corporations have been aggressive in exploiting these new opportunities, and have, in doing so, re-written the rules of economic engagement and have challenged the established principles of juridical boundaries and state sovereignty. Accordingly, they are now able to exert considerable influence not only on the markets within which they operate, but also on foreign affairs policy and international relations.

Whilst it cannot be denied that the power and influence of transnational corporations provide employment, income and, and in some instances, country wealth, this increase in power and influence has what has been described as a 'darker side' (Eden \& Lenway, 2001; Stiglitz, 2002) - economic devastation, and the ability to operate outside the human rights obligations assumed by each state pursuant to their status as a signatory of various human rights conventions, hence being able to avoid the accountability implications when violations are alleged to have occurred.

As a result of this ability to potentially circumvent human rights obligations, the dialogue as to the responsibilities of transnational corporations has increased, and given the impact of the current global economic crisis, the relationship between transnational corporations and human rights has never been more significant. This paper will contribute to the discussion of the relationship between globalization, transnational corporations and human rights in two ways: firstly, by arguing that whilst transnational corporations have been key beneficiaries of globalization, and often criticised for human rights abuses, they are more strategically placed than ever, as a result of the global financial crisis, to impact directly upon human rights, and: secondly, by arguing that traditional human rights 
dialogue has changed as a result of the global financial crisis, as concern for economic and financial welfare within developed countries replaces concern for human rights violations within developing countries.

This paper is divided into four parts: In the first part of this paper, various definitions of globalisation will be discussed and the significance of the similarities in definition will be highlighted. The second part will provide an understanding of the growth and influence of transnational corporations. The third part will provide an analysis of the relationship between globalization, transnational corporations and human rights, and in the final part, the challenges presented by the recent global financial crisis will be discussed in the context of human rights dialogue and the role of the transnational corporation. This article concludes that the global financial crisis has had a direct impact upon our perceptions of human rights and has shifted the focus away from traditional concerns for human rights violations, to more economic and financial sustainability issues.

\section{Defining Globalization}

There has been much written on the topic of globalization, but there is a common thread throughout the literature, and that is that globalization cannot be stopped, and that it is inevitable. Howard-Hassmann (2005) argues that globalization impels social change which in turn contributes to greater moves towards democracy, the rule of law, and the promotion of civil and political rights.

What then is globalization? It is clear that the term has many meanings (Garcia, 1999) and whilst the lack of an accepted definition can, in certain circumstances, be problematic, it seems that in this instance, there is no specific controversy with its lack of firm meaning. Indeed, when one reviews some of the definitions that have been ascribed to the term, they all have one thing in common - they all identify that the concept of globalization represents a changing world order driven by economic, political, financial and associated factors. According to Sjolander (1996: 604) globalization is "...an economic, political, social, and ideological phenomenon which carries with it unanticipated, often contradictory, and polarizing consequences." Robertson (1992:102) carries through the contradictory theme, when he states that globalization is a "...form of institutionalization of the two-fold process involving the universalisation of particularism and the particularization of universalism." A more basic definition is provided by MacEwan (1994: 1) when he calls globalization, "The international spread of capitalist exchange and production relationships", thus emphasizing the significance of capitalism. This should be compared to a more complex approach taken by Held and McGrew (1993) when they describe the concept of globalization as a universal process transcending states and societies, resulting in interconnectedness or interdependence otherwise known as the modern world community.

Dunning (1998: 15) refers to the global economy which he describes as an economy "...in which there is a close economic interdependence among the leading nations in trade, investment and cooperative relationships, and where there are relatively few artificial restrictions on cross-border commerce, or discrimination against foreign affiliates". This interdependence leads to an re-evaluation of domestic macro-organisational strategies as well as the culture of decision-making, so as to optimize the manner in which the modes by which resources and capabilities within the territorial control of that economy, are created, upgraded and efficiently deployed. The International Monetary Fund (1997) has defined globalization as "...the rapid integration of economies worldwide through trade, financial flows, technology spillovers, information networks, and cross-cultural currents. ” Joseph Stiglitz in his work Globalization and its Discontents (2002: 9-10) describes globalization as "...the closer integration of the countries and peoples of the world which has been brought about by the enormous reduction of costs of transportation and communication, and the breaking down of artificial barriers to the free flow of goods, services, capital, knowledge and (to a lesser extent) people across borders." He notes that it has been accompanied by the creation of new institutions to work across borders, that it is powerfully driven by international corporations, and has led to renewed interest in the activities of long-established international intergovernmental agencies such as the United Nations. Finally, Seita (1997: 431) encapsulates the varying definitions when he states that globalization "... is a multifaceted concept encompassing a wide range of seemingly disparate processes, activities and conditions...connected together by one common theme: what is geographically meaningful now transcends national boundaries and is expanding to cover the entire planet. Globalization has led to an awareness that international issues, not just domestic ones, matter."

Whatever the definition adopted, what is clear is that globalization has largely been seen to be defined in economic terms, whether from a market or a regulatory perspective (Garcia, 1999). This implies that globalization is a positive contributor to the attainment of the economic preconditions for social, economic and cultural human rights by generating wealth, prosperity, and employment on the one hand, and facilitating economic and financial interaction between countries on the other. However, globalization is seen in a much different perspective by the World Commission on the Social Dimension of Globalization (2004) which argues that globalization has created a 
morally unacceptable and politically unsustainable global imbalance, with the wealth that globalization has created being unequally shared and the benefits not translating to those who are on the margins of the global economy. In other words, rather than providing the 'market' basis for the provision of economic, social and cultural rights, globalization has generated an 'at risk' environment where such rights have the potential to be traded away when they come into conflict with market forces which drive globalization.

The primary agent (Ostry, 1992; Anderson, 2010) behind the rapid growth of globalization is the transnational corporation, which has, through innovations in transportation and communication, and as a result of the hunger of developing countries for foreign investment, been able to extend operations and take advantage of favourable regulatory and financial environments created by developing countries which seek to attract the investment of such corporations. Two legitimate questions therefore arise: has globalization and the growth of transnational corporations undermined human rights and thus the benefits of social change which globalization was expected to bring in its wake; and, given the recent global financial and economic crises, has the influence and power of transnational corporations increased such that human rights are now more at risk of being traded away for the sake of economic viability.

\section{The Influence of Transnational Corporations}

According to Ruggie (2007) (Note 1) in 2006 there were seventy-seven thousand transnational firms across the globe, with an estimated 770,000 subsidiaries and millions of suppliers, and operating in more countries than ever before. What then is a transnational corporation? A transnational corporation can be defined as a firm or company that has the power and ability to coordinate and control operations in more than one country, even where actual ownership does not reside in that firm or company (Dicken, 2009). Hedley (1999: 215-216) states that a transnational corporation is "any enterprise that undertakes foreign direct investment, owns or controls income-gathering assets in more than one country, produces goods or services outside its country of origin, or engages in international production.” The United Nations Centre on Transnational Corporations (1988: s30) states that transnational corporations are:

"...enterprises irrespective of their country of origin and their ownership, including private, public or mixed, comprising entities in two or more countries, regardless of the legal form and fields of activity of these entities, which operate under a system of decision making, permitting coherent policies and a common strategy through one or more decision-making centres, in which the entities are so linked, by ownership or otherwise, that one or more of them may be able to exercise a significant influence over the activities of others and, in particular, to share knowledge, resources and responsibilities with the others."

Whatever the definition adopted, the ability of transnational corporations to shape and define the global economy is without dispute, as is their ability to influence the regulatory frameworks within which they operate or seek to operate, given that countries have significant variances in laws regulating economic activity. This capacity to influence cannot be under-estimated, and goes directly to the notion of state sovereignty, which provides that each state has the sovereign right to establish its own laws and regulations, which in turn determine not only the nature of economic activity within that state but also address civil, political and social rights within the borders of that state. Sovereignty as a concept has traditionally relied upon the identification of territorial border lines delineating the area within which a state's sovereignty was paramount and providing the basis upon which challenges to sovereignty from outside could be determined. However, it is arguable that transnational corporations play little heed to territorial boundaries and the concept of sovereignty which they represent, seeking rather to minimise regulation and control by playing one sovereign state off against another in pursuance of a favourable policy environment in which to operate. Stern (2000) reinforces this point when she notes that transnational corporations have the power to be able to compete with the power of sovereign states and that they can hamper their economic sovereignty over natural resources and economic wealth, as well as potentially hampering their political sovereignty. She cites the example of ITT which at the time of its operations in Chile when President Allende was overthrown had an annual turnover higher than the GDP of Chile.

Jochnick (1999) specifically refers to the growth of transnational corporations as a factor which has undermined state sovereignty and limited government prerogatives, especially within developing or host countries. He argues that the impact of this loss of sovereignty is particularly relevant in the area of economic, social and cultural rights. This could be described as governments within developing countries seeking to maximise economic growth by aligning their economic policy environment to be favourable to transnational corporations, whilst leaving the broader economic, social and cultural requirements of the state to lag far behind. As was stated by DaniloTûrk, the Special Rapporteur on Economic, Social and Cultural Rights in a special report in 1992: 
The flurry of many States romantically to embrace the market as the ultimate solution to all of society's ills, and the corresponding rush to denationalize and leave economics, politics and social matters to the whims of the private sector, although the theme of the day, will inevitably have an impact upon the full realization of economic, social and cultural rights."

Transnational financial corporations, such as the World Bank, the African Development Bank, the European Bank for Reconstruction and Development, and the International Monetary Fund also require consideration in this context. The common purpose of the development banks is to assist the economic growth of developing countries by financing development projects and programs, and promoting foreign investment. The purposes of the International Monetary Fund as stated in Article 1 of their Articles of Agreement include the promotion of international monetary cooperation, facilitating the expansion and growth of international trade, and the extension of short and medium-term financing to member countries experiencing temporary balance of payment problems. Whilst these transnational financial corporations can be said to be 'apolitical' in their mandated operations, even given the pressure that can be brought to bear on them from the United Nations (Morais, 2000) it is arguable that because any developing country seeking assistance from these financial institutions is required to meet specific structural economic adjustment policies as part of the loan requirements (Krasner, 1999), that these requirements facilitate the violations of human rights by decreasing welfare programs and policy initiatives, whilst at the same time, addressing the policy requirements of transnational corporations which are relied upon to attract and keep essential financial investment, central to the economic development of the country, a point emphasised by Tûrk (1992).

It has also been suggested (Richards, Gelleny \& Sacko, 2001) that because developing countries are particularly susceptible to internal shocks such as coups, civil war and terrorism which can result in a massive outflow of investments funds and the operations of transnational corporations, governments are more willing to suppress any threats to internal stability, and will use strategies which include repression and curtailment or denials of civil and political rights for their population.

It is not being suggested here that the financial institutions referred to above have directly facilitated the abuse of human rights. Indeed there is considerable evidence to suggest that such institutions have contributed significantly to the recognition of human rights by clearly indicating that regimes that do not uphold human rights and the rule of law will not be supported by the international community. However, transnational corporations invest in countries which have stable political and economic environments. In order to attract these corporations and investment, governments will do whatever is required to ensure that stability is seen to be evident, thus there is a desire to limit internal conflict and provide a policy environment which is attractive. If the structural requirements attached to foreign aid/official development assistance via the World Bank or the International Monetary Fund, for example, are too rigid for a developing country with a repressive regime, then it is possible that the investment of transnational corporations as an alternative source of assistance will become more attractive, and that the political motives behind encouraging such assistance will impact directly on the meeting of human rights obligations.

There is however one aspect of the operations of the World Bank which does warrant further discussion in this context and that is in relation to the activities of the International Finance Corporation, the private sector arm of the Bank. The International Finance Corporation (IFC) deals directly with businesses seeking funds to implement development projects within developing countries, usually in partnership with the host country. The policy of the IFC is to carry out all its operations in "an environmentally and socially responsible manner", requiring its business clients to comply with its environmental, social and disclosure policies, which cover such issues as the prohibition on child labour, and the rights of indigenous peoples. Any business seeking financing from the IFC is required to sign an investment agreement, and the failure to comply with the policies of the IFC can result in suspension or cancellation of the loan facility. However, whilst there might be the appearance that the IFC is able to ensure the human rights obligations of its business clients, in reality there is evidence which supports the view that not only is the IFC unable to monitor its business clients, but that it has funded development projects which have violated human rights. Kinley and Tadaki (2003-2004) cite the examples of the Chad Cameroon Project, where a number of environmental and social risks were not addressed in the Environmental Impact Statement provided by the project sponsor, the funding of the Yanacocha gold mine in Peru, and the previously mentioned involvement of Royal Dutch Shell in Nigeria, which was the beneficiary of a US\$15 million loan from the IFC, and implicated in the arbitrary execution of Ogoni activists in 1995.

Even given the abovementioned qualifications on the effectiveness of the World Bank or the IFC to monitor the activities of transnational corporations which receive funding, and given that equally neither the World Bank nor the IFC have any real influence over the activities of transnational corporations with which they have no contractual relationship, the fact that the Bank and the IFC are able to protect social and environmental human 
rights is significant. As Kinley and Tadaki (2003-2004) identify, economic, social and cultural rights are the ones most vulnerable to abuse by transnational corporations, primarily because they are the rights least protected under international human rights law and practice. By setting standards and policies, the Bank and the IFC act by default, as a means through which the behaviour of other transnational corporations can be gauged (Bradlow, 2001-2002).

Bradlow (1996) however implies that transnational financial corporations, such as the World Bank and the IMF, should not just set standards, but that funding should be refused or conditional upon the correction of human rights abuses, or that funding will be forthcoming only when it is satisfied that the operations to be funded will not facilitate the government of the developing country in continuing human rights abuses. Arguably, this would then require the transnational corporations seeking funding for development projects, to ensure that they met the funding obligations directed at the government of the country, so as not be to complicit in facilitating human rights abuses. Whether or not such requirements could be effectively monitored must be considered, and the difficulties of intervening in alleged human rights abuses by governments are well documented. However, these potential problems should not form the basis for a lack of consideration of their applicability.

\section{The Relationship between Transnational Corporations and Human Rights}

There can be no argument to the proposition that transnational corporations wield enormous power to control international investment, especially in developing countries, thus rendering governments in these countries highly receptive to the terms as presented by the transnational corporations. There are polarizing views as to what impact this means from the perspective of human rights. Monshipouri, Welch and Kennedy (2003) argue that because transnational corporations have a direct impact on the economic, political and social environment of the countries in which they operate, they have the ability to both positively and negatively affect individuals and human rights. This is because these corporations generate large amounts of both income and wealth for their host countries, and also provide high levels of employment in markets which traditionally are notable for their high levels of unemployment, albeit generally at very low levels of income.

Of course, transnational corporations theoretically operate within certain constraints, the main ones being the property rights, and contractual rights and obligations created by a state, which are the minimal pre-requisites for economic activity within its territorial borders. Whilst the state is the guarantor of such civil rights, including the right to enter into private contracts, the right to engage in market activity, and the right to own property, it also has the role as a welfare state, providing social rights, such as the rights to education, health care, and employment. Finally, the state is the guarantor of political participation rights, such as the right to vote and take part in the processes which determine public rules and policies. These combined rights provide stability to society and provide the foundation delineating the dimensions and limits of state intervention in private activities, as well as responsibilities towards the social communities within that state. As is stated in the preamble to the Universal Declaration on Human Rights:

"The General Assembly proclaims this Universal Declaration of Human Rights as a common standard of achievement for all peoples and all nations, to the end that every individual and every organ of society shall...promote respect for these rights and freedoms."

Transnational corporations are, of course, not governments, and therefore are not expected to have an influence over those human rights responsibilities of the sovereign state. However, globalization has rendered the notion of absolute state sovereignty somewhat anachronistic, and states, especially developing ones, have found that their authority over economic activity is increasingly being 'high-jacked' by the regulatory and policy demands of transnational corporations, and accordingly, other basic social rights are being increasingly left to the vagaries of the market, as determined by the policies designed to meet the requirements of economic activity, thus rendering them subject to the risk of violation. Hedley (1999) argues that it has become increasingly difficult for host states to distinguish between foreign investment costs and foreign investment benefits. If this is so, the risk of violation increases proportionally to the difficulty of distinguishing between costs and benefits.

Jochnick (1999: 62) argues that transnational corporations exert "... an inordinate influence over local laws and policies and their impact on human rights ranges from a direct role in violations, such as abuses of employees or the environment, to indirect support of governments guilty of widespread repression." There are clearly documented examples of where the activities of transnational corporations have violated human rights: the Union Carbide chemical leak in Bhopal, India (Stephens, 2002); the Nike, Disney and Levi Strauss sweatshops in such countries as Indonesia (Nazeer, 2011); the Wal-mart factories in China and Honduras (Clade \& Weston, 2006) ; the case of Royal Dutch/Shell in Ogoni, Nigeria (Wiwa, 2000); the operations of Unocal Oil Corporation in Myanmar (Chambers, n.d.) the policies of British Petroleum in Columbia (Human Rights Watch, 1998); and the actions of Texaco in Ecuador, and Freeport-McMoRan in Indonesia (Ballard, 2001). 
Where a transnational corporation invests in a state with a repressive government and or a region where there is political unrest, Stephens (2002) argues that it is impossible for the corporation to operate without becoming complicit in human rights violations, even if it is just on the basis of security concerns as to property and employees. She cites several examples including the high profile Unocal case (Note 2) which was settled by Unocal in 2005 by the payment of compensation to the plaintiffs who had alleged forced labour, rape and murder by the Burmese military.

It should not be implied that transnational corporations seek out repressive regimes in which to maximise corporate profit, but there can be no argument that these corporations seek to minimize production costs by taking advantage of varying costs of labour, capital and raw materials, the most significant factors in this being lower labour costs and reduced environmental scrutiny.

The key human rights issues which are of concern relate to both civil and political rights as well as economic, social and cultural rights and include the prohibition on slavery, the right to rest and leisure, the right to a satisfactory standard of living, the right to a healthy environment, the rights of women and children, and the right to a social and international order to realise the freedoms stated. The realisation of these rights, as it has been previously stated, are the responsibility of the state and as has been argued, non-state actors, such as transnational corporations do not have direct responsibility under international law, to ensure that such rights are met.

However, transnational corporations do have an indirect responsibility, and it can be argued, an increasing indirect responsibility as a result of the contraction in the availability of funds to developing countries as a result of the global financial crisis. The financial liberalization of international markets which preceded the global financial crisis saw the unrivalled growth in the breadth and mobility of foreign direct investment and portfolio investment. Accordingly, investment in developing countries can be used as leverage to gain beneficial tax and labour policies, thus holding policy development of the developing countries hostage to the desires of the 'investor'. The greater the amount of international capital being invested the greater the potential for favourable policy constraint. This environment as been called the "race to the bottom" (Richards, Gelleny \& Sacko, 2001: Nandy \& Singh, 2009), where tax, labour safety, wage standards and social welfare programs are compromised in order to attract the investment. Richards et al (2001) state that in this environment, transnational corporations extract more money than they invest, that they displace local capital, contribute to unemployment by promoting labour-intensive production, receive substantial tax breaks which erodes the tax base of the developing country and, hinder the redistribution of social benefits.

As Stiglitz (2007: 196) succinctly stated:

"Globalization has compounded the problems arising from the misalignment of incentives to modern corporations. Competition among developing countries to attract investment can result in a race to the bottom, as companies seek a home with the weakest labor and environmental laws."

$\mathrm{He}$ also identifies another important consideration which warrants mention in this context. Transnational corporations arguably live by a different moral code in their home environment, as being part of the local community they take some moral responsibility for their conduct, even if that responsibility is not by compulsion of law. He argues that a transnational corporation operating overseas, employs a weaker moral code of responsibility, founded on the belief that the workers are "...lucky to have jobs, or that overall the country benefits from their investment..." this is despite the fact that they would not treat their workers or their home environment in the manner which they routinely apply offshore. Even where it is clear that a transnational corporation has breached local laws and regulations, the ability to successfully prosecute the corporation is problematic from two perspectives. Firstly, developing countries need the transnational corporations to bring in the jobs that the economy desperately needs, so there is a clear imbalance of power, which can be exploited by the corporation. Secondly, transnational corporations operate with limited liability with the parent company located in a jurisdiction outside the control of the developing country. In the event that there is a disaster in which the transnational corporation is involved, such as the Bhopal disaster in 1984 involving Union Carbide, the home country of incorporation may well refuse to cooperate in any prosecution. So if the transnational corporations withdraws, the government of the developing country is left not only with the outcome of the disaster which it doubtless is unable to fund to clean up, but it faces the loss of both ongoing and prospective investment, as other transnational corporations will be discouraged from investing in a country willing to take legal action against them for breaching local laws and regulations, or it may demand even more unfavourable terms than the previous corporation in order to engage in that investment. 


\section{The Impact of the Global Financial Crisis}

The onset of the recent global financial crisis and the subsequent global economic crisis has provided a new dimension to the relationship between human rights and transnational corporations. The financial liberalization which is at the heart of globalization, saw many countries including developing countries open their doors not only to transnational corporations, but also saw them open their banking sector to large international banks. Stiglitz (2007) argues that transnational corporations, such as Coca-Cola, IBM and Microsoft prefer to deal with the large international banks rather than local banks, the result being that local banks are unable to compete, see their own sources of funding dry up and are often taken over the by the international banks. If local businesses are unable to meet the funding criteria of the large international banks, they are unable to operate, and the consequence for the local community and the developing country as a whole is significant.

The global financial crisis however created a new set of parameters which arguably have impacted directly upon developing countries. The financial crisis which followed the collapse of the US sub-prime market saw a major contraction in the worldwide availability of funds and an increase in the cost of acquiring funding. Developed economies plunged into recession or near recession, with declining housing prices, increasing unemployment, the failure of banks or their bailout by governments, and the use of stimulus payments pumping large amounts of money into the economies of the developed countries to avoid even worse economic disaster from occurring.

Developing countries are by their very nature, poor, and burdened with debt, leaving many struggling to avoid default. Many developing countries borrow or are lent too much, with terms and conditions which force them to bear most if not all of the risk of increases in interest rates, as the cost of funding increases, fluctuations in exchange rates and, and associated economic factors. Stiglitz (2007) further argues that once a developing country faces the probability of default, and economic collapse, then the country is a hostage to international assistance, and faces a loss of economic sovereignty.

The risk that exists in the post global financial crisis world for developing countries is that in facing insurmountable debt burdens which then, as is the case in Greece at present, require austerity measures to be instituted, programs which directly address human rights are the first to be cut. For example, the austerity measures currently being instituted in Greece include major cuts to pensions, employment, welfare programs and education. Countries subject to austerity measures are required to develop economically so as to generate the funds necessary to repay their debt, but to do so, they must attract investment from transnational corporations. This power imbalance is clear and the consequences obvious. Transnational corporations seek to reduce costs and increase profit, while developing countries seek to provide employment and income. As this paper has discussed, to attract foreign investment, developing countries need to provide a policy environment which will attract that investment, whether it comes by way of infrastructure or by the use of outsourcing. Inevitably there will be a clash between meeting economic demands and human rights obligations. Given that at best, economic, social and cultural rights are to be progressively realised, and that in many developing countries, the acceptance of such rights is ideologically contentious, then the possibility for a policy environment favourable to transnational corporations and unfavourable to the meeting of human rights obligations is real.

\section{Conclusions}

Transnational corporations are in a position to have an enormous impact upon human rights, and as has been suggested, that impact can be either positive or negative (Anderson, 2000) Many transnational corporations have adopted voluntary codes of conduct, with some enforcing their codes very seriously by imposing strict internal controls in order to deter unethical or illegal behaviour. (Note 3) However, as is well known, codes of conduct, as well-meaning as they may be, are voluntary and until an effective regulatory model (Note 4) for the extraterritorial regulation of transnational corporations with respect to human rights obligations is developed, then transnational corporations will continue to operate with virtual impunity (Kolk, van Tulder \& Welters, 1999). Yes, in theory, transnational corporations can legitimately and justifiably be made subject to international human rights obligations by the countries within which they operate. In reality however, a country struggling economically and pressured to meet external debt obligations is unlikely to attempt to impose such obligations. As has been discussed in this paper, transnational corporations seek a positive policy environment in which to operate. The imposition of legally enforceable obligations which specifically address human rights issues may indeed counter that positive policy environment sought by the corporation, and see that corporation move its attention and possible investment to a country which does not seek to regulate in that manner.

Globalization has bought with it some major challenges in international law and transnational corporations focus significantly in the debate over how to regulate the realities of this new world order of a global economy. Whilst we search for the most appropriate international legal frameworks and international courts to ensure the smooth 
functioning of this global economy, we should not forgot that at the heart of globalization are people, disadvantaged and desperate merely to sustain a very basic existence. Transnational corporations are neither total villains nor total benefactors. The work of such organisations as Amnesty International and Human Rights Watch and the advent of new technologies such as the internet, have done much to bring to the attention of the world that human rights abuses are occurring, and many transnational corporations have changed their practices to meet the moral outrage that has followed disclosure. However, human rights abuses are still occurring in the form of child labour, environmental damage, unsafe and unhealthy working conditions including exposure to hazardous products, unfair contractual obligations, and inadequate remuneration, to name a few. The risk is that in a post global financial crisis world that these abuses will continue as developing countries struggle with even greater debt burden and poor economic outlook, seeking investment by creating a policy environment which places human rights in its shadow.

Human rights are not just the rights of those in the developed or the developing world. They belong to the international community and it behoves governments and the international community to work more diligently towards a global framework which whilst embracing the good of globalization, protects the vulnerable of developing countries from ongoing human rights abuses.

\section{References}

Anderson, J. C. (2000). Respecting Human Rights: Multinational Corporations Strike Out. University of Pennsylvania Journal of Labor and Employment Law, 2(3), 463-506.

Bacjer, L. C. (2005-2006). Multinational Corporations, Transnational Law: The United Nations' Norms on the Responsibilities of Transnational Corporations as a Harbinger of Corporate Social Responsibility in International Law. Columbia Human Rights Law Review, 37, 287-389.

Ballard, C. (2001). Human Rights and the Mining Sector in Indonesia: A Baseline Study. [Commissioned report]. International Institute for Environment and Development, London, U.K.

Bradlow, D. D. (1996). The World Bank, the IMF, and Human Rights. Transnational Law and Contemporary Problems, 6, 47-90.

Bradlow, D. D. (2001-2002). Should the International Financial Institutions Play a Role in the Implementation and Enforcement of International Humanitarian Law? University of Kansas Law Review, 50, 695-729.

Chambers, R. (2010). The Unocal Settlement: Implications for the Developing Law on Corporate Complicity in Human Rights Abuses. Retrieved from http://www.wcl.american.eduu/hrbrief/13/unocal.pdf?rd=1

Claude, R. P., \& Weston, B. H. (Eds.). (2006). Human Rights in the World Community: Issues and Action. Philadephia: University of Pennsylvania Press.

Dicken, P. (1992). International Production in a Volatile Regulatory Environment: The Influence of National Regulatory Policies on the Spatial Strategies of Transnational Corporations. Geoform, 23(3), 303-316. http://dx.doi.org/10.1016/0016-7185(92)90044-5

Dicken, P. (2009). Globalization and Transnational Corporations. In International Encyclopedia of Human Geography (pp. 563-569). Elsevier Ltd. http://dx.doi.org/10.1016/B978-008044910-4.00170-X

Dunning, J. H. (1998). The Global Economy, Domestic Governance, Strategies and Transnational Corporations: Interactions and Policy Implications. In N. Kobayashi (Ed.), Management: A Global Perspective (pp. 3-39). Tokyo: The Japan Times.

Duruigbo, E. (2008). Corporate Accountability and Liability for International Human Rights Abuses: Recent Changes and Recurring Challenges. Northwestern University Journal of International Human Rights, 6, 222. Retrieved from http://www.law.northwestern.edu/journals/jihr/v6/n2/

Eden, L., \& Lenway, S. (2001). Multinationals: The Janus Face of Globalization. Journal of International Business Studies, 32(3), 383-400. http://dx.doi.org/10.1057/palgrave.jibs.8490973

Garcia, F. J. (1999). The Global Market and Human Rights: Trading Away the Human Rights Principle. Brooklyn Journal of International Law, 25, 51-97.

Hedley, R. A. (1999). Transnational Corporations and Their Regulation: Issues and Strategies. International Journal of Comparative Sociology, 40, 215-230. http://dx.doi.org/10.1177/002071529904000202

Held, D., \& McGrew, A. (1993). Globalisation and the Liberal Democratic State. Government and Opposition, 28, 262-291. http://dx.doi.org/10.1111/j.1477-7053.1993.tb01281.x 
Henkin, L. (1999-2000). That "S" Word: Sovereignty, and Globalization, and Human Rights Et Cetera. Fordham Law Review, 68, 1-14.

Howard-Hassmann, R. E. (2005). The Second Great Transformation: Human Rights Leapfrogging in the Era of Globalization. Human Rights Quarterly, 27, 1-40. http://dx.doi.org/10.1353/hrq.2005.0006

Human Rights Watch. (1998). Columbia: Human Rights Concerns Raised by the Security Arrangements of Transnational Oil Companies. New York: HRW.

International Finance Corporation. (2009). Disclosure Policy. Washington, DC: IFC. Retrieved from http://www.ifc.org/ifcext/disclosuure/nsf/Content/Disclosure_Policy

International Monetary Fund. (1992). Articles of Agreement. Washington, DC: IMF.

International Monetary Fund. (1997). World Economic Outlook - May 1997. Washington, DC: IMF.

Jochnick, C. (1999). Confronting the Impunity of Non-State Actors: New Fields for the Promotion of Human Rights. Human Rights Quarterly, 21, 56-79. http://dx.doi.org/10.1353/hrq.1999.0008

Kinley, D. \& Tadaki, J. (2003-2004). From Walk to Talk: The Emergence of Human Rights Responsibilities for Corporations at International Law. Virginia Journal of International Law, 44, 931-1023.

Kolk, A., Van Tulder, R., \& Welters, C. (1999). International codes of conduct \& corporate social responsibility: Can Transnational Corporations Regulate Themselves? Transnational Corporations, 8(1), 143-180.

Krasner, S. D. (1999). Sovereignty: Organized Hypocrisy as cited in Backer, L.C. (2005-2006) Ideologies of Globalization and Sovereign Debt: Cuba and the IMF. Penn. St. Int'l L. Rev. 24, 497-561.

Macewan, A. (1994). Globalisation and Stagnation. Monthly Review, 45, 1-16.

McCorquodale, R., \& Fairbrother, R. (1999). Globalization and Human Rights. Human Rights Quarterly, 21(3), 735-766. http://dx.doi.org/10.1353/hrq.1999.0041

Monshipouri, M., Welch, C. E., \& Kennedy, E. T. (2003). Multinational Corporations and the Ethics of Global Responsibility: Problems and Possibilities. Human Rights Quarterly, 25, 965-989. http://dx.doi.org/10.1353/hrq.2003.0048

Morais, H. V. (2000). The Globalization of Human Rights Law and the Role of International Financial Institutions in Promoting Human Rights. The George Washington International Law Review, 33, 71-96.

Nazeer, A. (2011). Corporate Globalization \& human rights abuses in the sweatshops of Pakistan, Indonesia \&Vietnam. Retrieved from http://www.articlesbase.com/international-studies-articles/corporate-globalization-and-human-rights-in-thesweatshops-of-pakistan-indonesia-and-vietnam-4223353.htm

Ostry, S. (1992). The domestic domain: The new international policy arena. Transnational Corporations, 1, 7-26.

Ratner, S. R. (2001). Corporations and Human Rights: A Theory of Legal Responsibility. The Yale Law Journal, 111, 443-545. http://dx.doi.org/10.2307/797542

Richards, D. L., Gelleny, R. D., \& Sacko, D. H. (2001). Money with a Mean Streak? Foreign Economic Penetration and Government Respect for Human Rights in Developing Countries. International Studies Quarterly, 45, 219-239. http://dx.doi.org/10.1111/0020-8833.00189

Robertson, R. (1992). Globalization: Social Theory and Global Culture. London: Sage. http://dx.doi.org/10.1177/026327692009001011

Ruggie, J. G. (2007). Business and Human Rights: The Evolving International Agenda. The American Journal of International Law, 101(4), 819-840.

Scherer, A. G., Palazzo, G., \& Baumann, D. (2006). Global Rules and Private Actors: Towards a new Role of the Transnational Corporation in Global Governance. Business Ethics Quarterly, 16(4), 505-532. http://dx.doi.org/10.5840/beq200616446

Seita, A. Y. (1997). Globalization and the Convergence of Values. Cornell International Law Journal, 30 , 429-492.

Sjolander, C. T. (1996). The Rhetoric of Globalization: What's in a World? International Journal, 51(4), 603-616. http://dx.doi.org/10.2307/40203150

Skogly, S. I., \& Gibney, M. (2002). Transnational Human Rights Obligations. Human Rights Quarterly, 24, 781-798. http://dx.doi.org/10.1353/hrq.2002.0040 
Stephens, B. (2002). The Amorality of Profit: Transnational Corporations and Human Rights. Berkeley Journal of International Law, 20, 45-90.

Stern, B. (2000). How to Regulate Globalization. In M. Byers (Ed.), The Role of Law in International Politics (pp. 247-268). Oxford: Oxford University Press.

Stiglitz, J. (2002). Globalization and its Discontents. London: Penguin.

Stiglitz, J. (2004). Making Globalisation Work. London: Penguin.

Türk, D. (1992). The Realisation of Economic, Social and Cultural Rights (Final Report)of the Sub-Commission on Prevention of Discrimination and Protection of Minorities. United Nations.

Universal Declaration of Human Rights. Retrieved from http://www.un.org/en/documents/hdhr

Westfield, E. (2001-2002). Globalization, Governance, and Multinational Enterprise Responsibility: Corporate Codes of Conduct in the $21^{\text {st }}$ Century. Virginia Journal of International Law, 42, 1075-1108.

Wiwa, \& Royal Dutch Petroleum. Retrieved from http://ccrjustice.org/wiwa

\section{Notes}

Note 1. The data supplied by Ruggie is from an analysis of the 2006 United Nations Conference on Trade and Development(UNCTAD). The 2011 World Investment Report (available at http://www.unctad-docs.org/files/UNCTAD-WIR2011-Ful-en.pdf) details an extensive breakdown of transnational corporations by categories, including top 100 financial TNC's, top 100 non-financial TNC's, top 100 financial TNCs by Geographic spread, as well as by developing and developed countries, acquisition of foreign assets and other such categories. The inclusion of these figures by Ruggie is to provide an overview of the extensive nature of TNCs. A more detailed discussion of TNC's and their breakdown is the subject of a forthcoming paper by this author.

Note 2. It is interesting to note that subsequent to this litigation, Chevron, which had acquired Unocal, sought to force its insurers to reimburse the company for the compensation it had paid to the plaintiffs in the original action. Unocal's insurers had refused to reimburse Unocal for the settlement and were sued by Unocal. In Lexington Insurance Company v Union Oil Company of California, No. BC 30774, 2007, Judge Elizabeth Grimes of the Superior Court of California in Los Angeles dismissed Unocal's claim on the basis that the insurance policy in question excluded coverage for 'military terrorism', one of the claims made by the original plaintiffs in the litigation against Unocal.

Note 3. The Code of Conduct for Chevron contains a clear statement as to the human rights obligations of the Company and its employees. Rio Tinto similarly have a global code of business conduct which addresses human rights obligations. See: http://www.chevron.com/documents/pdf/chevronbusinessconductethicscodes.pdf and http://www.riotinto.com/documents/The_Way_we_work.pdf

Note 4. The United Nations Economic \& Social Council, Sub-Commission for the Protection and Promotion of Human Rights in August 2003, drafted and adopted the Economic Social and Cultural Rights: Norms on the Responsibilities of Transnational Corporations and Other Business Enterprises with Regard to Human Rights (available at http://ap.org/documents/alldocs.aspx?doc_id=7440 ) These Norms were favoured by human rights, labour and environmental groups, but were coolly and controversially rejected by the business community which led to their subsequent rejection by the now defunct UN Human Rights Commission, theparent body of the Sub-Commission. The position of Special Representative on Human Rights and Transnational Corporations was appointed in 2005. For a discussion on this issue and to read comments on the view of Special Representative see Duruigbo, E. (2008) 'Corporate Accountability and Liability for International Human Rights Abuses: Recent Changes and Recurring Challenges' 6, Northwestern Journal of International Human Rights, 222. 